\title{
Adam Braun
}

mgr inż.

BUDIMEX S.A.

adam.braun@budimex.pl

DOI: 10.35117/A_ENG_16_10_03

\section{The potential of the IT support in monitoring and maintaining of railway earthworks}

\begin{abstract}
This paper addresses the sources and problems about obtaining archival documentation of railway construction research for ongoing investments. It aims at indication of the guidelines for monitoring of buildings during its erection and operation. The article presents technical possibilities of the continuous monitoring of earthworks and civil engineering facilities. The author offers architecture of data flow which is helpful in monitoring and maintaining the rail networks and takes into account modern IT technologies.
\end{abstract}

Keywords: Archival records Geotechnical; Monitoring the building of railway; Database

\section{Circulation geotechnical archival documentation}

The current guidelines of research of ground subsoil for the construction and modernization of railway infrastructure marked as Igo-1 [17] define very precisely the requirements for the fulfilment for research of ground of rail structures used in the design, programming and execution of geological works. The study also outlines the research methods as well as ways of interpretation and presentation of results. One of the principal objectives of the guidelines Igo-1 is "appropriate and rational design, construction and operation of linear and engineering objects as well as railway infrastructure."

To fully develop the design documentation it is necessary to obtain geotechnical data. Since the current investments are characterized by a high rate of implementation, there is a pressure to as soon as possible provide designers with the results of studies of grounds on which the investment will be realized. From time to time, happen also disasters of railway buildings requiring urgent repair. In order to meet the expectations of customers, people developing the geotechnical documentation at an early stage can provide their own or derived from geological archives data about subsoil. The guidelines Igo-1 [17] define the following sources of geological archival data:

1. Archive test results, held by the National Archives Geological or Investor (on paper):

a) geological - engineering documentation,

b) geotechnical documentation,

c) hydrogeological documentation,

d) documentation of deposits ,

e) documentation of geophysical surveys,

f) documentation of drilling research of various types.

2. Information from databases and registries conducted by institutions and / or state authorities (mainly in the electronic version):

a) database of network NATURA 2000 [25]

b) mineral resources database and register of mining areas MIDAS [13]

c) Central Geological Database (CBDG) [5]

d) Geological and Engineering Database (BDGI) [4] 
e) database on the areas of imminent flooding (OBZP) - currently being conducted by the National Water Management Information System as a project of the National Guards against extraordinary threats (ISOK) [12]

f) database of Coordination Centre - Information (OKI) - currently led by the Operations Centre of the Regional Water Management in Cracow as Geoportal SPLASH [9]

g) register of direct threats to harm and damage to the environment

h) State environmental monitoring SEM [15]

i) list of data about the environment and its protection [25]

j) surveying - geological documentation of liquidated mining plants (documentation only in paper form) [21]

k) regional banks pollution,

1) publicly accessible lists of data about the environment and its protection [25]

m) topographic database BDOT [3]

n) database of hydrogeological data $\mathrm{CBDH}[6]$.

According to the current regulations [20], geological information is owned by the State Treasury. Access to geological information is paid in the case of studies that were not funded by the State budget, and would be used for commercial purposes. Because of the need to make payments on obtaining archival information, companies implementing geotechnical documentation for railway investment use primarily their own documentation or use research results available by the Investor (PKP Polish Railways PKP or Centre of Investments). The obtained archive geotechnical studies from companies of the PKP group are characterized by a large variety of data presentation. The presentation forms depend mainly on informatics technology tools used by the company managing the documentation and the ability of geotechnicians to interpret the results of studies. Unfortunately, the data obtained in this way are processed but not raw data. The processed data are recorded mainly in the files of the type $*$.pdf and *.dwg and often do not have the exact location of the performed tests, which makes any it difficult. Raw data are information obtained directly from the examining device (e.g. profile of ground penetrating radar, chart from CPT probe, GPS location recorded when measuring, etc.).

The idea of exploiting the results of archival geotechnical studies for the implementation of ongoing investments is justified by economic and practical reasons. Unfortunately, the opportunities arising from the progress of information are used to a very small extent to archive and share ground surveys. One of the main reasons leading to problems with obtaining archival data on existing groundwater conditions of railways building are obligatory for the existing contractors of researches, very general contractual provisions in the ongoing investment processes. An example of a model of archiving geotechnical tests can be the geodesic post-completion documentation archived by the Railway Documentation Centre of Geodesy and Cartography. In the current conditions of the contract for railway projects are detailed regulations describing the form and content of the data, which is received by the contracting authority for its surveying archival resources. In contrast to the requirements for geotechnical documentation where there is no detailed presentation, to contracting authority, the expected forms of data transfer from researches. Tender records for archiving documentation invoke to the applicable guidelines Igo-1, which refer to the applicable regulations requiring the transfer of only part of the documentation (e.g. engineeringgeological and hydrogeological) to geological archives conducted by the State Geological Survey. The remaining part of the geotechnical documentation realized in the framework of the investment is passed post-completion documentation and archived in individual Works Railway Lines and partly in the Documentation Archive Railways PKP SA. 
Obtaining relevant information for the needs of design or fast repair of railway construction is currently very difficult from geological archives of data listed in the guidelines Igo-1. For example, in an electronic database of documentation points (CBDG) are available only a few results of surface ground layers realized in the construction of motorways, expressways and several mines. At the beginning of September 2016,in the portal CBDG could be found only a few results of ground surveys carried out in the framework of recently completed investments related to railway infrastructure. Figure 1 shows a fragment of the ditch in sation Pęgów on line 271 Wroclaw Główny - Poznan Główny, as an example of public electronic geological data from the portal CBDG 2016.

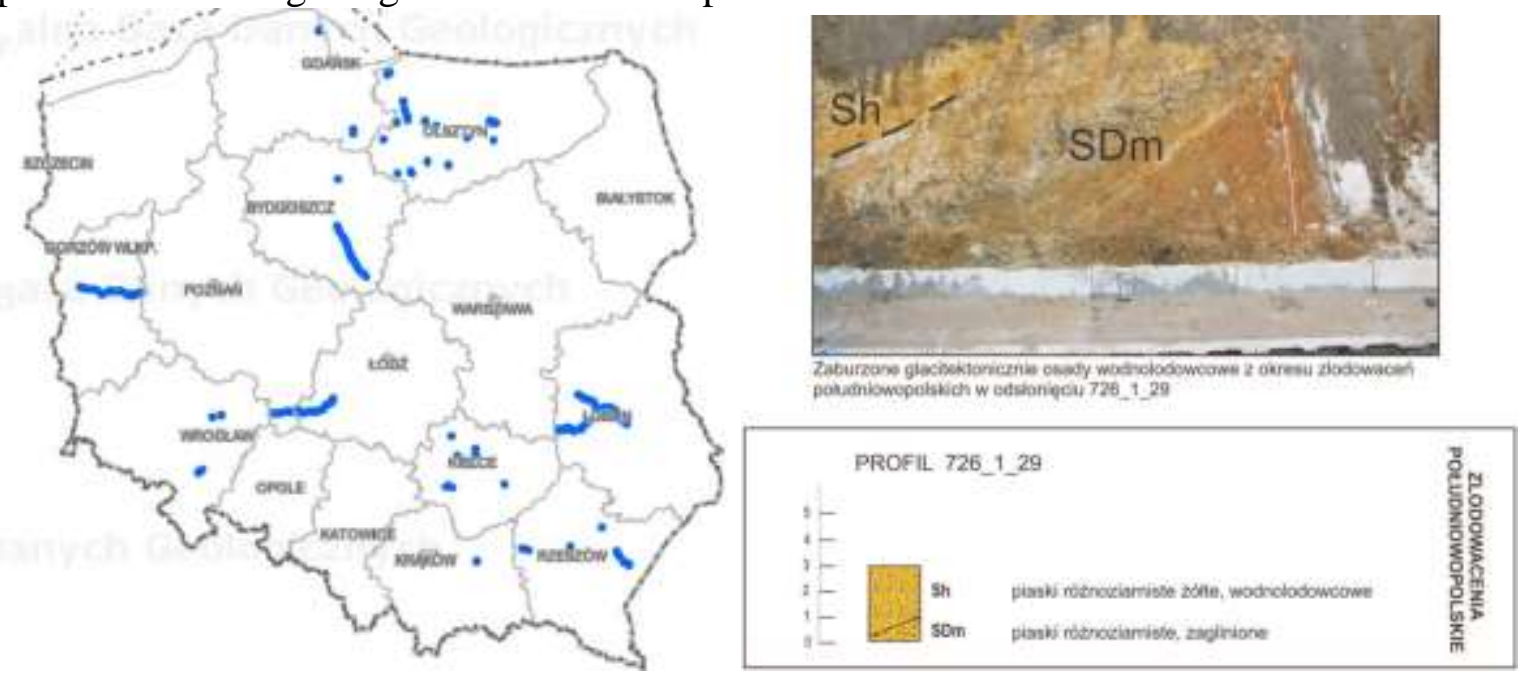

1. Location of archival research of documentation points PIL with a sample profile of $3 \mathrm{~m}$ ditch. Source: PIG-PIB Central Geological Database [14].

Due to the lack of full, quick and cheap access to archival research in the ongoing railway infrastructure projects, there is a rule that the contractors preparing the geological documentation evaluate and independently carry out research of ground. In a very small extent are used archival materials drawn up in the context of previous investments, which are located in the traditional archives of Purchaser. Besides to the costs incurred in carried out studies again in the same locations that were made in the context of previous investments, the lack of a thorough diagnosis of the existing soil and water conditions in relation to the already built investment of technical infrastructure (drainage, dredging, reinforcement by geosynthetics, piling etc.) can lead to a substantial increase in the cost of construction due to unexpected building catastrophe.

Polish Geological Institute - National Research Institute has been realizing since 2006 the project Protective System Against Landslide (SOPO) [23]. This project is a very valuable source of information about existing landslide risks not only for landowners but also for designers and contractors. Thanks to publicly accessible Carts of Registration Landslides and Threatened Areas gathered in a public database SOPO, we can prevent potential landslide movements. In the nineteenth and twentieth century, the railway ground constructions were carried out without exhaustive analysis of existing ground conditions. Therefore, as a result of destructive exogenous processes repeatedly occurred on the railway lines landslides, landfalls, canoeing, soil creeping etc. having a negative impact on the economic aspects of the management of PKP network. In the technical literature on geodynamic interactions is a lot of information about the structure of the damage railway. Unfortunately, access to archival material defining the locations and ways to repair the railway construction is so difficult that experts implementing project documentation and conducting infrastructural investments often 
do not receive the appropriate data dedicated to the purpose of proper modernization and revitalization of existing railway line.

\section{Monitoring and maintenance of railway buildings}

The guidelines Igo- 1 require (by the application of the provisions Eurokod'u 7 [18]) the monitoring of railway construction not only at the stage of the investment, but also in the exploitation phase. The idea is to use the data obtained from the stage of ground recognition to design work, management of the investment's realization and control of the building after its completion. The objective is to obtain assurance that the designed structure (the protective layer, embankment slope, ditch, engineering object) satisfies the assumptions of the designer about its behaviour during exploitation.

To ensure compliance with the requirements of the designer's assumptions, documentation of observations of built structures should be preserved. In addition, the guidelines Igo-1 require not only the implementation of observation of structure's behaviour, but also impose an obligation to interpret the results of observation after time with assessing the assumptions. For this purpose, guidelines Igo-1 impose an obligation to keep the "Programme of monitoring of buildings" on the railway infrastructure manager. Technical conditions on maintaining the railway subgrade Id-3 [14] impose an obligation of "Registration cards of weak (endangered) places in the railroad bed." Both methods of monitoring make necessary to create paper documentation. Quality of the hand-created documentation and interpretation of the results depends largely on the qualifications of the personnel involved in this purpose. Since the manager of Polish rail network has limited financial resources to achieve its objectives, he was forced in recent years to optimize the workplace, thereby limiting his potential for realizing the documentation of endangered places. According to the author of this work, a cheap and effective solution to the current financial and organizational problems would be digitization of archival data combined with implementation of selected elements of the geological documentation in digital form (e.g. on the areas subjected to geodynamic influence). The digital data could be aggregated in one place managed by a competent team of specialists skilled in geotechnical issues. Thanks to the computer tools, they would be effectively protected against any loss, immediately made available via the Internet (or Intranet) and occupy very little space.

Guidelines Igo-1 and the terms of Id-3 propose to observe movements as the basic method of diagnostics of building construction. In justified cases, monitored is also the state of underground water. Experts on subgrade point out rightly that during the inspection, and even geodetic monitoring can only be detected visible signs of damage or threat of substructure [7]. They suggest that managers should conduct measurements of the state of the track using suitably configured measuring trolleys. On the standard measurement trolleys (Figure 2), one can install a modern measuring device, e.g. the locator-type GPS configured with the device LIDAR scanning with laser displacement (operating in a similar way to radar but uses light instead of radio waves), ground penetrating radar studying the structure of ballast and rail substructure and two thermal imaging cameras with wide-angle $\left(180^{\circ}\right)$ recording the conducted inspection. Since the errors of measurements from e.g. the imperfection of railway tracks overlap the test results from the so-configured measuring trolleys, ambiguous results would have to be verified in more detail by specialists sent to inspect the identified weaknesses in the subgrade or construction of the railway. 


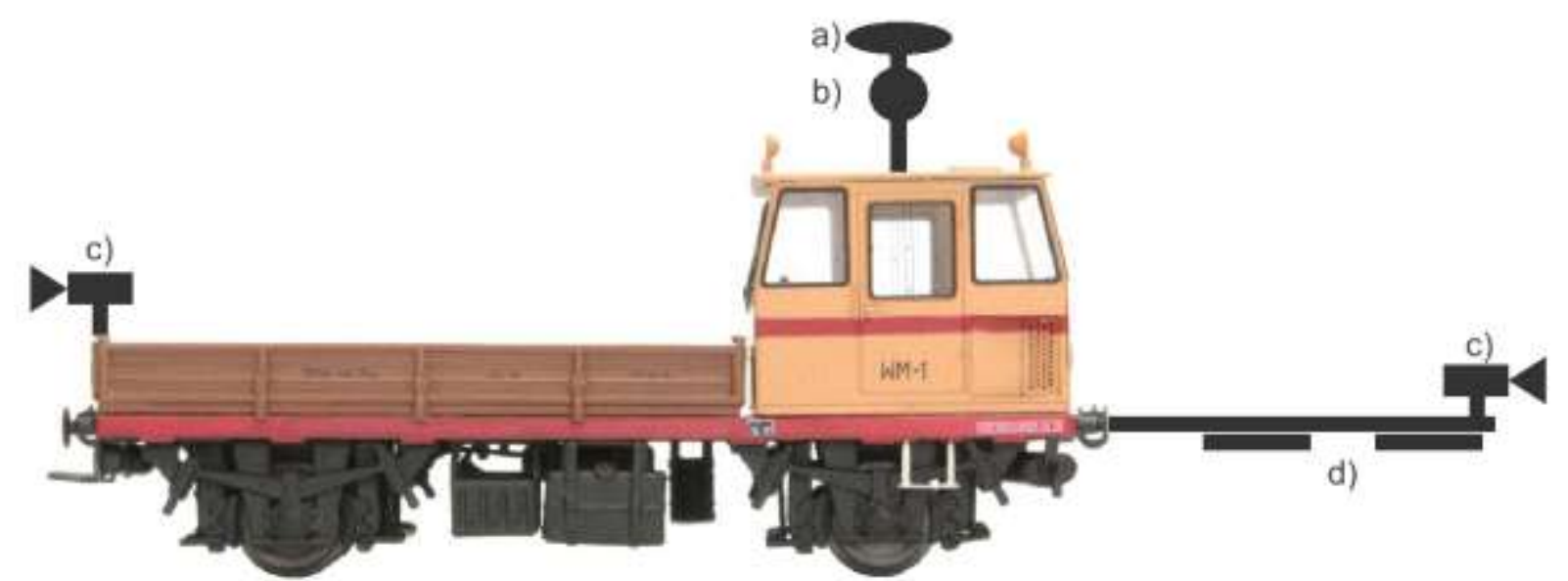

2. Measuring trolley equipped with a GPS device (s), LIDAR (b), the two cameras 180 (c) and GPR (d).

Monitoring the rail surface and a protective layer are designed to recognize the dynamics of emerging changes in time. Also subsidence of new and built on embankments on weak substrates should be recorded in the course of increasing burden. The inspection should use a plot of settlement for each layer of pavement and subgrade, so that one can determine the factors influencing the occurrence of defects. In recent years, there has started an intensive development of optoelectronics used in the geodetic works. For several years, geosynthetic measuring mats with fibre optic sensors are available on the market [24]. The principle of operation of such sensors is based on a linear change in the length of Bragg's reflected wave, which is directly proportional to changes in temperature and stress. Point sensors (the length of a single sensor is a few millimetres) are "entered" into a core fiber (glass [GOF] or more flexible polymeric $[\mathrm{POF}]$ ) enabling multipoint measurement of stress and temperature in real time of linear geotechnical structures.

Immediate identification of areas subjected to mass movements is the main advantage of sensory cables. Quick identification of endangered construction allows taking immediate response in the form of intensified observation. In addition, by using artificial intelligence systems in analytical systems, it is possible to "teach" the system to respond only to the phenomena occurring in the railroad bed, which significantly jeopardize the construction because of potential disaster occurrence. Tests carried out under the project IJkdijk in the Netherlands [8] proved the usefulness of the application of sensory cables to monitor earthy building.

Experiments conducted on experimental earthen buildings show that already a few days before the onset of the disaster, one can locate the precursors of the internal erosion of the soil structure with pre-installed sensory cables (Figure 3). Thanks to locating the areas exposed to failure, operational service may react with advance by e.g. the restriction or closure of railway traffic and thus prevent costly consequences of failure. Since currently it is the most accurate method of observation movements earth buildings, it would be worth to apply it to selected sections of Polish railways. The proposed railway objects dedicated to the remote monitoring by means of sensory fibre optic cables (POF) are:

- areas subjected to geodynamic movements (landslide areas, karst and exposed to the influence of mining),

- high embankments, modernized for the purpose of increasing the speed of trains,

- embankments which perform the hydro-technical function. 


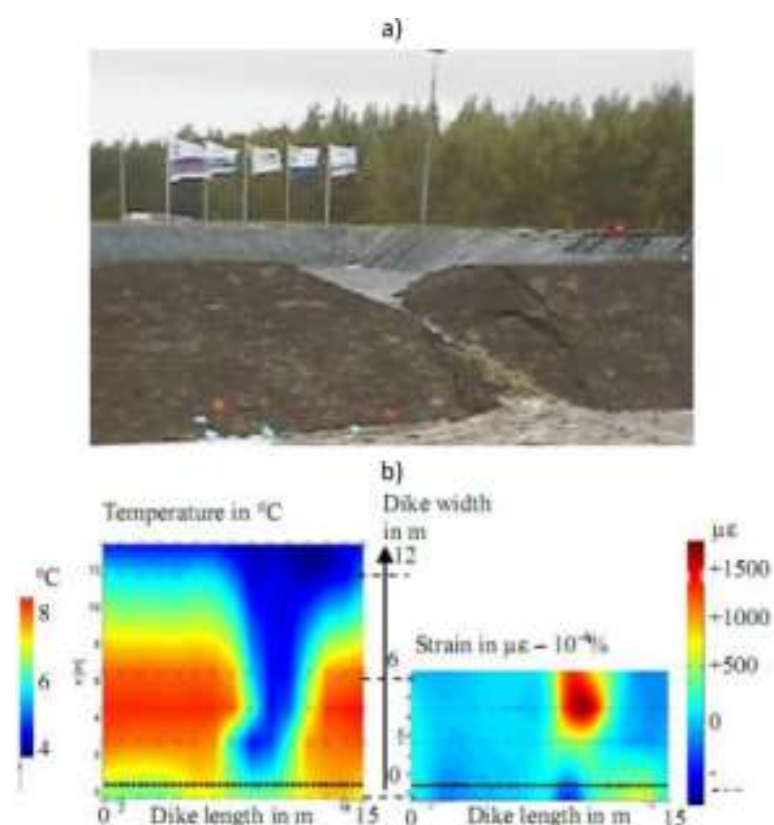

3. Experimental embankment in the project IJdijk in the time of its processing (a);

embankment (b); experimentally destroyed building earthy building and results of measurements of deformation from four sensor cables in the period of three days prior to the failure (c); [3].

\section{Support System of Maintenance Railway Structures}

For the use by the manager of the Polish rail network with digital tools monitoring railway structures (LIDAR, sensory cables, ground penetrating radar, video recording, etc.) it is necessary to process and archive massive amounts of data. In order to successfully processing the collected data would be created a management system for digital database, the so-called Data Warehouse (Figure 4). Due to the value of information contained in the existing operating system data, the proposed support system should be created on the basis of the data contained in them (e.g. the base Sokone, SOKOR, SOHRON etc. [2]). 


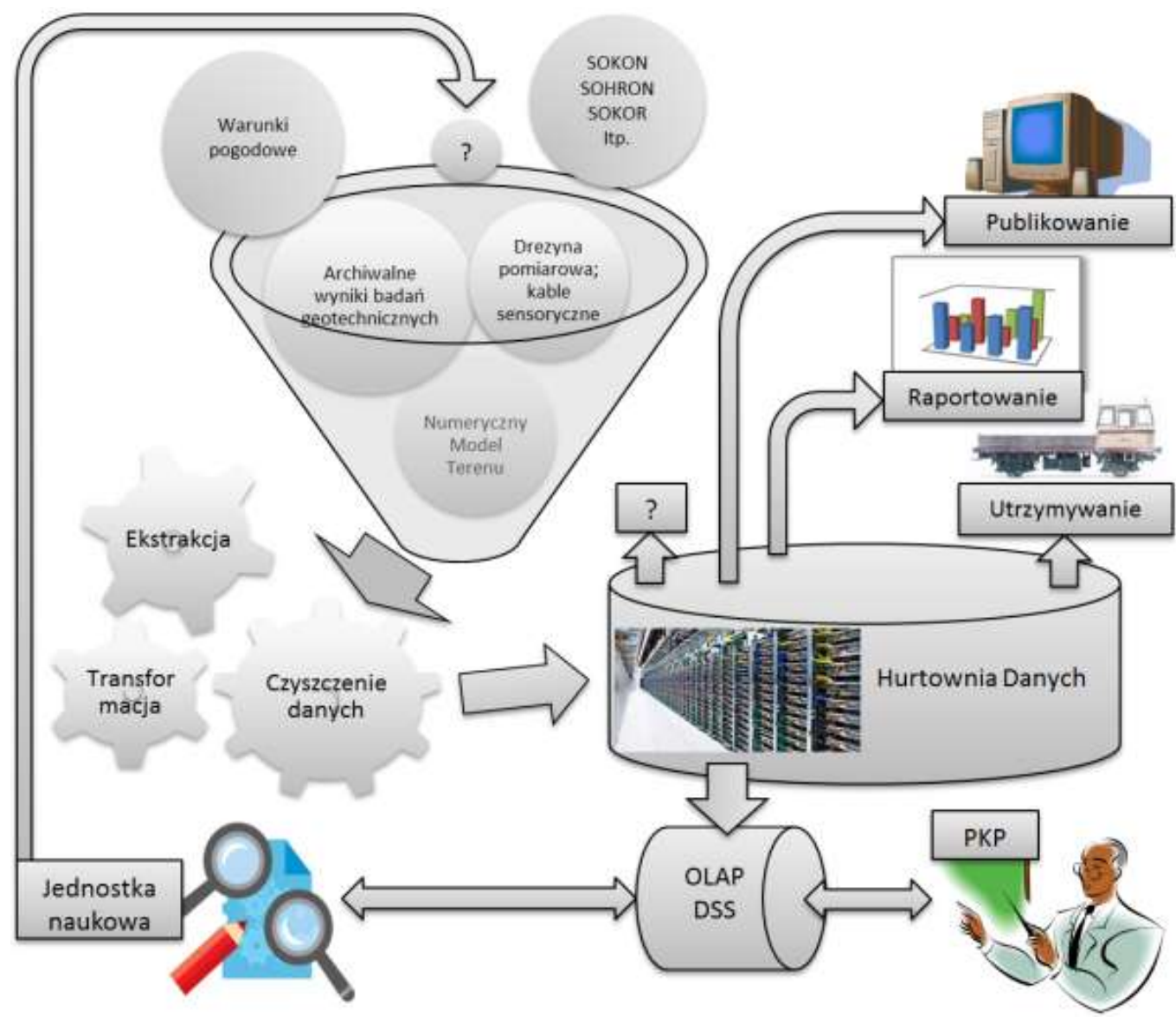

4. Architecture of data flow supporting the maintenance of the railway network

The digital system supporting maintenance of railway construction consists of the following information tools:

a) System of Online Analytical Processing (OLAP). It is a new Information technology helpful in making management decisions. This system can help in planning, decision making and control of project realization by the possibility of a multidimensional and multivariate comparing data from the past as well as their use in the creation of simulation models. The OLAP system could be used in the development and control of the implementation of strategic decisions, e.g. undertaken under the National Programme for Railway.

b) Decision Support System (DSS). This software provides comprehensive information to support decision-making at all levels of management in PKP Polish Railway Lines SA. A user of DSS system has remote and dynamic insight into the existing ground conditions through numerical documentation, particularly useful in prevention or repairing sudden accidents. The system could also be used by scientific institutions. By access to the information collected in the data warehouse (e.g. the existing ground conditions, built rail pavement, prevailing weather conditions, traffic load, etc.), one would determine the cause of emerging defects in the pavement and/or subgrade. By identifying the cause of the emerging fault, one can develop a corrective action that may have an impact on the need to collect new and updated information in the data warehouse from functioning railway structures (e.g. propagation velocity of Rayleigh's surface waves in modified ground).

c) Archiving systems and profile sharing numerical documentation. An example of such a system is the portal CBDG [5] managed by the Polish Geological Institute - National 
Research Institute. Its successor will likely be an introduced tool called GEOINFONET, which will be available through e-learning platform PUAP. Thanks to the archiving system is possible:

- aggregation of geotechnical data (often heterogeneous) derived from different sources at different times,

- explore the possibility of geotechnical data according to the principle "from general to specific" (levels of aggregation),

- homogeneity of archived geotechnical data,

- remote, dynamic access to digitized archival materials.

The described above Digital Support System of Maintenance Structural Rail solutions based on the data flow systems operating in the financial corporations [11]. Due to the nature of the management of railway network, the system of data flow was supplemented with scientific institutes, which help build new technical solutions based on the experience of the functioning of the railway construction (anti-vibration materials, fixing of rails, etc.). The system is characterized by low operating costs (for the current functioning backup system), the possibility to performed the dynamic monitoring and immediate response to appearing event, correlation data obtained from various sources, immediate access to historical information, etc.

\section{Summary}

Implementation of monitoring railway buildings can be significantly automated. By using sensory optic cables collecting online (dynamically) information about the movements, operational services can very quickly join the remedial action, even before the onset of serious flaws in the construction.

Thanks to the development of computer techniques, we are witnessing a revolution in the field of information management. Methods based on operational systems processing data are becoming more expensive. The functioning operating systems are aimed to create standard reports that support the current activities of railway companies. A few databases scattered throughout the country, operating often only in a paper form, make it difficult to report and analyse historical data. In the case of electronic data, it happens that a change of computer system prevents access to archived data stored in a different form of writing. Model processing operating data does not help enough in their analysis and making based on them the appropriate management decisions [11]. Systems processing data analytically can influence the process of taking decisions. Access to data describing the functioning the railway construction in the long term allows to perform analysis, search for anomalies or patterns in work of individual structural elements. OLAP system can support management by providing the relevant information needed to analyse the problem or situation, necessary for right people at the right time at low costs.

\section{Source materials}
[1] Archiwum
Dokumentacji
Mierniczo
Geologicznej

http://www.wug.gov.pl/o_nas/archiwum_dokumentacji, wrzesień 2016r.

[2] BAŁUCH Henryk „Problemy monitorowania szyn i ich miejsce w systemie GISRAIL"; Problemy Kolejnictwa - Zeszyt 140; 2008r.

[3] Baza danych obiektów topograficznych

(BDOT) http://www.geoportal.gov.pl/dane/baza-danych-obiektow-topograficznych-bdot\#, wrzesień 2016r.

[4] BDGI http://geoportal.pgi.gov.pl/atlasy_gi/projekt, wrzesień 2016r.

[5] CBDG http://bazagis.pgi.gov.pl/website/cbdg/viewer.htm, wrzesień 2016r.

[6] Centralny Bank Danych Hydrogeologicznych (CBDH), http://spdpsh.pgi.gov.pl/PSHv7/ 
[7] DĄBROWSKI Adam, OCHOCIŃSKI Krzysztof, SKRZYŃSKI Eugeniusz „Zjawiska osuwiskowe na polskiej sieci kolejowej” Problemy Kolejnictwa - Zeszyt 162 (2014), Wydawnictwo: Instytut Kolejnictwa, Warszawa 2014.

[8] GĄSIOR Paweł, KALETA Jerzy, POPRAWSKI Lech „Monitorowanie stanu technicznego obiektów hydrotechnicznych z wykorzystaniem systemów SHM", https://www.researchgate.net/publication/ 2011.

[9] Geoportal PLUSK http://mapy.plusk.eu/imap/, wrzesień 2016r.

[10] Interaktywna mapa obszarów NATURA 2000 http://geoserwis.gdos.gov.pl/mapy/, wrzesień 2016r.

[11] KOPCZEWSKI Marian, CIEŚLIK Tomasz, CZAPIK-KOWALEWSKA Ewa, KRAWCZYK Joanna; „Procesy decyzyjne w oparciu o hurtownie danych”, Politechnika Koszalińska 2013r.

[12] Krajowy Zarząd Gospodarki Wodnej, Informatyczny System Osłony Kraju przed nadzwyczajnymi zagrożeniami (ISOK) http://mapy.isok.gov.pl/imap/

[13] MIDAS http://geoportal.pgi.gov.pl/portal/page/portal/MIDASGIS/start, wrzesień 2016r.

[14] Państwowy Instytut Geologiczny. Zasady sporządzania dokumentacji geologiczno inżynierskich. Warszawa: Ministerstwo Środowiska i PIG, 1999.

[15] Państwowy Monitoring Środowiska (PMŚ) http://inspire.gios.gov.pl/portal/, wrzesień 2016r.

[16] PKP Polskie Linie Kolejowe S.A. „Warunki techniczne utrzymania podtorza kolejowego Id-3", PKP Polskie Linie Kolejowe S.A. Warszawa 2009r.

[17] PKP Polskie Linie Kolejowe S.A. „Wytyczne badań podłoża gruntowego dla potrzeb budowy i modernizacji infrastruktury kolejowej Igo-1". Warszawa: PKP Polskie Linie Kolejowe S.A. Centrum Realizacji Inwestycji, 2016.

[18] PN-EN 1997-1:2008 Eurokod-7 - Projektowanie geotechniczne - Część 1:Zasady ogólne.

[19] Rejestr bezpośrednich zagrożeń szkodą w środowisku i szkód w środowisku http://rejestry.gdos.gov.pl/, wrzesień 2016r.

[20] Rozporządzenie Ministra Środowiska z dnia 19 grudnia 2001 r. w sprawie gromadzenia i udostępniania próbek i dokumentacji geologicznych (Dz U z 2001 r., nr 153, poz.1780)

[21] SEGI-AT Sp. z o.o.; Instytut Ochrony Środowiska; Krakowskie Przedsiębiorstwo Geologiczne ProGeo Sp. z o.o. Zasady sporządzania dokumentacji określających warunki hydrogeologiczne w związku z projektowaniem dróg krajowych i autostrad. Warszawa: Ministerstwo Środowiska, 2006.

[22] SKRZYŃSKI Eugeniusz „Problemy modernizacji i rewitalizacji podtorza” Problemy Kolejnictwa - Zeszyt 167 (2015), Wydawnictwo: Instytut Kolejnictwa, Warszawa 2015.

[23] System Osłony PrzeciwOsuwiskowej http://geoportal.pgi.gov.pl/portal/page/portal/SOPO/aplikacja, wrzesień 2016r.

[24] WOSNIOK Aleksander, KRYWULT Łukasz, LIEHR Sascha, KREBBER Katerina, WENDT Mario, CHROST Andrzej; „Monitoring konstrukcji ziemnych przy zastosowaniu rozłożonych przestrzennie światłowodowych sensorów optycznych, zintegrowanych w geosyntetykach", Górnictwo i Geoinżynieria, Zeszyt 22011.

[25] Wykaz danych Generalnej Dyrekcji Ochrony Środowiska http://wykaz.ekoportal.pl/ , wrzesień $2016 r$. 